\title{
An integrated approach to energy use: the case study of the ACEA site
}

\author{
Viviana Negro $^{1, *}$ and Davide Mainero ${ }^{1}$ \\ ${ }^{1}$ ACEA Pinerolese Industriale S.p.A., Engineering Department, 10064, Corso della Costituzione 19, Pinerolo, Italy
}

\begin{abstract}
Currently, ACEA utilises biogas obtained from the treatment of the organic fraction of municipal solid waste for thermal and electric energy recovery through endothermic engines ( $3 \mathrm{MW}$, in total). By 2020, the biogas produced at the site will no longer be used as a fuel for the combined heat and power units, but it is expected to feed a purification system in order to obtain a flow of biomethane to be injected into the natural gas network. This is part of the Italian strategy to achieve the Horizon 2020 European targets aimed at promoting the renewable production of transport fuels. In order to encourage sustainability and innovative prototype technologies, ACEA has also been involved in some European research projects, in particular for the conversion of biogas into other energy carriers. furthermore, ACEA ha recently built a flexible experimental platform that can used for the validation step of prototypes in an industrial field.
\end{abstract}

\section{ACEA integrated waste treatment district}

ACEA Pinerolese Industriale S.p.A. (or simply ACEA) is a modern multi-utility company located in Northern Italy, which currently provides services for municipalities, private companies and citizens, ensuring sustainable development in three main areas: water, energy and environment.

More specifically, the premise specifically dedicated to the environmental sector is called "integrated waste treatment district" since it encompasses four waste treatments plants (one wastewater (WW) treatment plant, one landfill, one composting plant and one anaerobic digestion (AD) plant) highly interconnected, according to which the waste stream from one may become the inlet stream for another facility. Furthermore, all the liquid effluents generated at the site from the composting plant, the anaerobic digester plant and the landfill are sent to the WW treatment plant. The digestate coming from the anaerobic process is sent to the composting plant, where it is used as a starting material for compost production, and the sludge deriving from the WW treatment plant. Finally, all the biogas produced at the WW treatment plant, at the landfill and at AD plant, is conveyed and temporally stored in the gas-holder for the production of renewable electricity and heat by means of combined heat and power (CHP) units exploiting biogas combustion. The site is an interconnected plant for the management of water, sludge/digestate and for energy recovery (both thermal and electrical).

The site is also an example of the integration of the anaerobic-aerobic treatment of the organic fraction of solid urban waste. In fact, ACEA utilises the digestate from the anaerobic digestion, together with green residue from separated urban collection, for the production of high-quality compost, registered under the FLORAWIVA brand, which has achieved a quality certification by the CIC (Consorzio Italiano Compostatori) in 2005. The electricity and heat surplus that is not utilised for internal consumption is sold to the grid; in fact, ACEA has realised a wide district heating network, serving a user basin of 30,000 inhabitants and a shopping centre, with an actual size of 7.6 MW, to be enlarged in coming years.

The current main core of the site is the combustion of biogas to produce heat and electricity from CHP units, however, by 2020 , all the biogas produced at the site is expected to feed a purification unit for the production of biomethane to be injected into the gas natural grid (up to $800 \mathrm{Sm} 3 / \mathrm{h}$ of biomethane produced), for enlarging the unit already present in the site, which currently produces bio-methane for transport fuel (up to $50 \mathrm{Sm}^{3} / \mathrm{h}$ of biomethane produced). This significant change from the ACEA perspective is aligned to the Renewable Energy Directive 2009/28/EC [1], since the European Union has significantly supported the policies aimed at the production of biofuels, including liquid or gaseous fuels such as biodiesel and biomethane produced from biomass. These biofuels are a renewable alternative to fossil fuels in the EU transport sector, strategically significant for reducing greenhouse gas emissions and improving the security of the EU supply. By 2020, Italy, in line with European policies, aims to ensure that $10 \%$ of transport fuel comes from renewable sources such as biofuels. At the ACEA site, the conversion from biogas to biomethane could be coupled with the use of natural gas from the grid (instead of the current use of biogas)

\footnotetext{
Corresponding author: viviana.negro@aceapinerolese.it
} 
for feeding the CHP units, in order to continue to ensure the energy needs, both electrical and thermal, of the plant.

\section{Energy production at ACEA premises}

ACEA is responsible for the organic fraction of municipal solid waste (OFMSW) collection applied directly from 150,000 inhabitants living in 47 municipalities in the south west of Turin close to the French border. The treatment of the OFMSW involves the anaerobic digestion process, since this process is widely considered as an effective waste biomass treatment approach [2]. Currently, the biogas plant treatment serves roughly 1 million inhabitants, managing $60,000 \mathrm{t} \mathrm{y}^{-1}$ of OFMSW (90,000 $\mathrm{t} \mathrm{y}^{-1}$ of OFMSW in the short term), which undergoes two anaerobic digesters, characterised by a total working volume of $5000 \mathrm{~m}^{3}$. The process is thermophilic $\left(55^{\circ} \mathrm{C} \pm 1\right)$ with a retention time of 14 days and an organic loading rate higher than 6 $\operatorname{kgTS~} \mathrm{m}^{-3} \mathrm{~d}^{-1}$. Every year, more than $4,000,000 \mathrm{Nm}^{3}$ of biogas, with an average methane content of $55 \% \mathrm{v} / \mathrm{v}$ and a calorific heat of around $5.4 \mathrm{kWh} \mathrm{m}^{-3}$, are produced, and used for ensuring heat and electricity to the site itself and the surrounding area.

\subsection{Thermal use of energy}

The thermal energy can be employed for several uses: heating up the fermentative broth for the AD process at $55{ }^{\circ} \mathrm{C}(5,070 \mathrm{MWh} / \mathrm{y})$, for the WW treatment plant $(1,400 \mathrm{MWh} / \mathrm{y})$, for the building uses $(1,170 \mathrm{MWh} / \mathrm{y})$ and for district heating $(6,380 \mathrm{MWh} / \mathrm{y})$ (data is for 2017). The thermal energy can be supplied by both the combustion biogas in the form of renewable energy $(3,710 \mathrm{MWh} / \mathrm{y})$ and by an external source $(10,310$ $\mathrm{MWh} / \mathrm{y}$ ), utilising natural gas from the grid. In fact, ACEA exploits two super-heated water boilers fuelled with natural gas for thermal energy production.

The use of thermal energy is strictly connected to the season of the year, as can be seen in Figure 1 (from April to September) and Figure 2 (from October to March). During the winter season, the heat produced is mainly used for district heating, reaching around $430 \mathrm{kWh} / \mathrm{h}$ at 8.00 am. From April to September, district heating requires no more than $85 \mathrm{kWh} / \mathrm{h}$, and the main consumption is allocated to the AD process. It can be noted that the maximum consumption of thermal energy is less than $300 \mathrm{kWh} / \mathrm{h}$ during the summer season, and more than double that during the winter season, since a higher amount of heat is necessary for the district heating and, to a less extent, to maintain the proper fermentation temperature at $55^{\circ} \mathrm{C}$.

\subsection{Electric use of energy}

Figure 3 shows the annual production and demand of electric energy, also highlighting the amount acquired from the external source and the quantity sold to the grid (data is for 2017). The renewable electric energy at the ACEA site is provided by three CHP units for biogas combustion (13,700 MWh/y) and 630 photovoltaic panels (130 MWh/y); however, there is a contribution from the network (690 MWh/y), to compensate for the lack of electricity due to the maintenance of the engines, breakdowns or lack of biogas in case of great demand. Furthermore, $92.7 \%$ of total amount of energy consumed within the site was renewable and obtained from biogas combustion and photovoltaic panels, while the remaining $7.3 \%$ was purchased from the network.

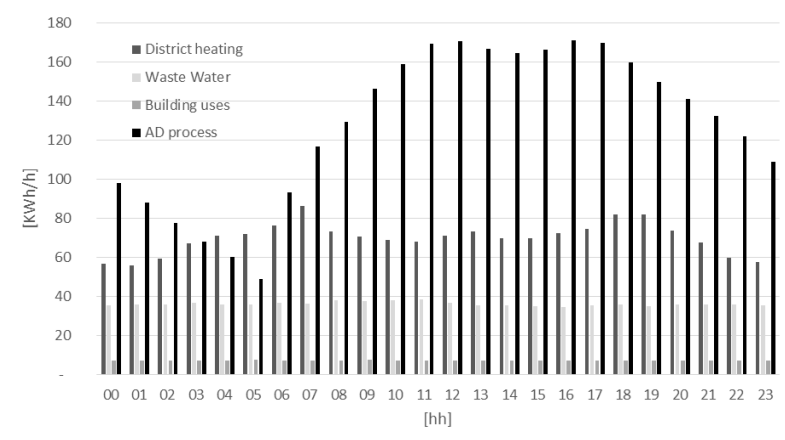

Fig. 1. Uses of thermal energy during the day, from April to September. Thermal energy is employed for district heating, for the wastewater treatment plant, for building uses and for the AD process. Data is for 2017.

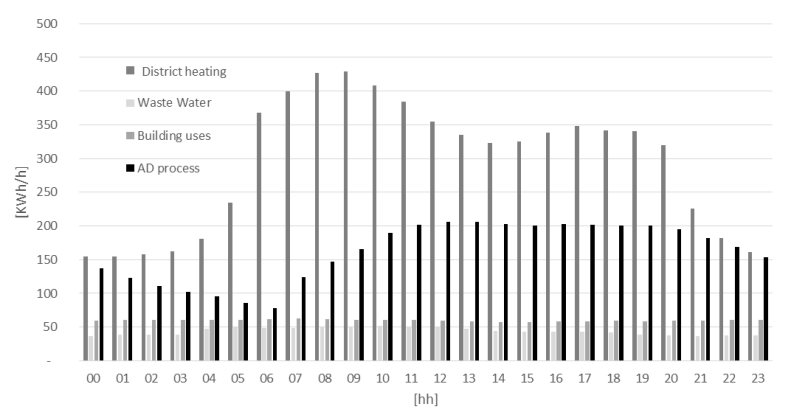

Fig. 2. Uses of thermal energy during the day, from October to March. Thermal energy is employed for district heating, for the wastewater treatment plant, for building uses and for the $\mathrm{AD}$ process. Data is for 2017.

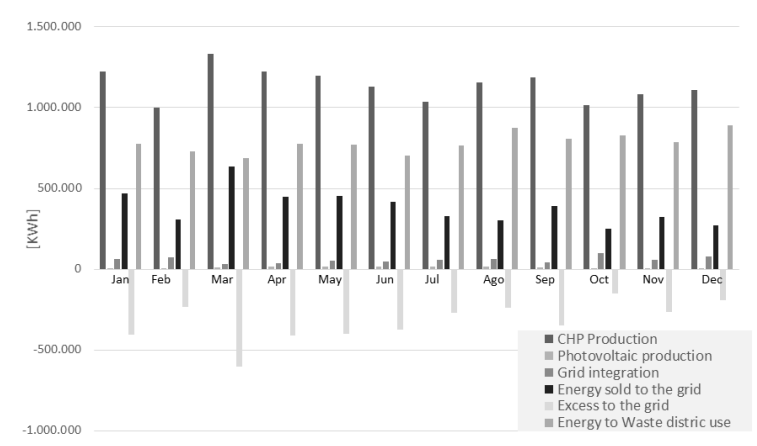

Fig. 3. Uses of electric energy during (2017). Electric energy derives from biogas combustion (CHP units), from photovoltaic production and from natural gas purchased from the network. The electric production can be used internally or sold to the network. 
In addition, $66 \%$ of the electricity energy is selfconsumed, and the remaining $34 \%$ is sold to the network. The net balance between the electricity purchased and sold to the network is then favourable towards transfer to the national network $(+3.9 \mathrm{GWh} / \mathrm{y})$, demonstrating that the amount of electricity sold to the grid $(4,590 \mathrm{MWh} / \mathrm{y})$ is definitely greater than that purchased from the external source (natural gas for super-heated water boilers).

\section{Energy production at ACEA premises}

Within the EU Framework Program Horizon 2020, ACEA experiments with new technologies for the realisation of innovative prototypes to make renewable energy production as efficient as possible. Among the others, in this concept, there are two projects worthy of note, PROGEO and BIORURPLUS (funded by others; in this concept, there are two projects worthy of note, PROGEO and BIOROBURPLUS. PROGEO (funded by the EU Framework Program Horizon 2020 H2020EU.3.3, H2020-EU.2.3.1.) is focused on the conversion of $\mathrm{CO} 2$ (gaseous effluent from biomethane upgrading) and $\mathrm{H} 2$ (from water electrolysis) into bio-methane through a methanation reactor by means of Sabatier reaction, for ensuring the chemical storage of renewable energy [3]. All the biogas produced by $\mathrm{AD}$ may be theoretically converted into biomethane to be fed into the grid. In fact, methane is a well-known and widely used fuel and all technologies related to methane storage and distribution are fully available, and ACEA has its own infrastructure to inject it into the grid. Since the hydrogen production from water electrolysis is very demanding of energy, this process is sustainable only when it is possible to utilise low-price electricity (during the night) and the off-peak periods of electricity production. This will be part of the scope of the demonstration project and the ACEA site is expected to perform a demonstration of the $500 \mathrm{~kW}$ PROGEO modular unit in order to achieve the final technology readiness levels (TRL) of 8 .

BIOROBURPLUS involves the development of a direct biogas oxidative steam reformer for the production of bio-hydrogen to be utilised as inlet streams for fuel cell devices. In fact, BIOROBURPLUS (funded by the EU Framework Program Horizon 2020 -JTI-FCH-20161) claims to develop an entire pre-commercial fuel processor delivering $50 \mathrm{Nm} 3 / \mathrm{h}(107 \mathrm{~kg} / \mathrm{d})$ of $99.9 \%$ hydrogen from different biogas types (landfill gas, anaerobic digestion of organic wastes, anaerobic digestion of wastewater-treatment sludge) in a costeffective manner. A dedicated TRL6 demo campaign $(>4400 \mathrm{~h}$ ) will be carried out in the last six months of the project at ACEA premises for the production and purification of bio-hydrogen.

For both cases, ACEA represents the ideal industrial site to validate results obtained from intensive research work, and to assess the production cost and market price of renewable products, in order to be competitive with the traditional market.

\section{Conclusion}

From the beginning, the company proposed a new model of development, where waste is considered as a resource, and a new business model, able to improve and offer innovative solutions, rooted in the surrounding area for environmental and social sustainability. The ACEA site is currently involved in an adaptation to the most modern and innovative technologies, in line with the new environmental requirements established by the European directives on energy and emissions. The ongoing activities include the complete conversion from biogas to biomethane production and, in parallel, an increase in the thermal recovery from the CHP and the total conversion of the CHP from biogas to natural gas. From this perspective, attention is on the aim of producing only the electric energy strictly necessary for the internal consumption of the integrated waste treatment district. The goal of the optimisation process is increasing the efficient use of energy within the single industrial processes.

The authors would like to thank the European Commission for financial support for the BIOROBURPLUS project (grant agreement $n^{\circ} 736272$ ) in the EU Framework Program Horizon 2020 -JTI-FCH-2016-1 and PROGEO project (grant agreement $\mathrm{n}^{\circ}$ 717957) EU Framework Program Horizon 2020 -EU.3.3 and EU.2.3.1.

\section{References}

1. EC, Directive 2009/28/EC [Online]. Available: https://eur-lex.europa.eu/legalcontent/EN/ALL/?uri=celex\%3A32009L0028

[Access date : 20 March 2019].

2. H. Ma, Y. Guo, Y. Qin, Y. Li, Bioresource technology, 269, 520-531 (2018).

3. J. Uebbing, L.K. Rihko-Struckmann, K. Sundmacher, Applied Energy, 233-234, pages 271282 (2019). 